\title{
The Onset of Lactase Persistence in Europe
}

\author{
Pascale Gerbault \\ Research Department of Genetics, Evolution and Environment, University College London, \\ London, UK
}

\section{Key Words}

Lactase persistence · Neolithic period - Allele surfing •

Positive selection · Ancient DNA

\begin{abstract}
The genomic region containing the lactase $(L C T)$ gene shows one of the strongest signals of positive selection in Europeans, detectable using a range of approaches including haplotype length, linked microsatellite variation and population-differentiation-based tests. Lactase is the enzyme that carries out the digestion of the milk sugar lactose. Its expression decreases at some point after the weaning period is over in most mammals and in around $68 \%$ of all living adult humans. However, in some humans, particularly those from populations with a history of dairying, lactase is expressed throughout adulthood. This trait is called lactase persistence (LP), and in people of European ancestry, it is associated with a single mutation $(-13910 * T)$. Evidence from the detection of dairy fat residues in potsherds, and allele frequencies in ancient DNA samples suggest that LP arose after dairying practices had developed. However, the reasons why LP may have been advantageous are still debated, and the respective contribution of demography and natural selection remains to be disentangled. This paper discusses various studies, from archaeology to population genetics, that have shed some light on the subject by investigating the evolution of LP in Europe.

(c) 2014 S. Karger AG, Basel
\end{abstract}

(c) 2014 S. Karger AG Basel

0001-5652/14/0764-0154\$39.50/0

\section{Lactase Persistence and Natural Selection}

The lactase gene (LCT) encodes the small intestine enzyme lactase or lactase phlorizin hydrolase, responsible for the cleavage of the milk sugar lactose into its two monosaccharide components glucose and galactose $[1,2]$. Without lactase, lactose reaches the colon, where it is fermented by colonic bacteria. Products of this fermentation and osmotic effects generate symptoms of lactose intolerance, including abdominal cramps, bloating, flatulence, or diarrhea [3]. Lactase activity is high in young mammals, including most humans, but decreases after weaning [4]. This is the case for most adults worldwide [5], except for about 32\% who show a persistence of lactase activity throughout their lifetimes. This phenotype is termed lactase persistence (LP) and has only been observed in humans.

The genomic region surrounding LCT has been widely identified as a striking example of a region that shows strong signals of positive directional selection. In European genomes, this effect is detected using tests which show extended haplotype lengths [6-8], a reduced diversity of linked microsatellites [9] and a high population differentiation $[10,11]$. These signals of strong selection are associated with a single nucleotide polymorphism (rs4988235, C>T) of which allele $-13910^{*} T$, located at 13910 nucleotides upstream of the transcription start of LCT, is causal of LP [12-14]. Estimates of the selection coefficients of this allele range from 0.3 to $19 \%$ using a co-

\section{KARGER}

E-Mail karger@karger.com

www.karger.com/hhe
Pascale Gerbault

Research Department of Genetics, Evolution and Environment

University College London, Darwin Building, Gower Street

London WC1E 6BT (UK)

E-Mail p.gerbault@ucl.ac.uk 
alescent approach [15], from 0.8 to $1.8 \%$ using a demic approach [16], from 5.2 to $15.9 \%$ using a spatially explicit simulation modeling approach [17] and from 9 to $19 \%$ using genetic variation [6]. These high selection coefficients are attributable to the fact that the allele is so widespread, yet the date estimates for the expansion of the allele are relatively recent: $2,188-20,650$ years before present (BP) using extended haplotype variation [6], 7,475-10,250 years BP using closely linked microsatellite variation [18], $6,256-8,683$ years BP using simulation modeling [17] and $1,500-64,900$ years BP using a coalescent approach [15].

The $-13910^{*} T$ allele enhances lactase activity both in vitro $[13,14]$ and in vivo [12]. It is noteworthy that four additional variants, located in the same genomic region, are also associated with LP in other geographic regions [5] and have been shown to enhance lactase expression in vitro [19-23]. This suggests that the LP is a case of parallel selection, or convergent evolution [21-25]. The coexistence of several alleles in a single geographic location alters the patterns of diversity and provides a different signature of selection [20-22].

While the reasons why LP may have been positively selected remain to be addressed, they are likely to differ between distinct geographic regions [26, 27]. Interestingly, LP is not evenly distributed worldwide $[3,5,28]$, but appears to be more frequent in populations with a history of dairying $[29,30]$.

\section{The Archaeological Context of Dairying}

The earliest archaeological evidence for dairying dates back to the beginning of an archaeological period called the Neolithic. The Neolithic refers to the transition from a subsistence strategy mainly based on hunted and gathered species to one where domesticated crop and animal species tended to predominate. The archaeological record shows that the most ancient evidence for farming economies lies in the Near East (approx. 10,500 years ago), while farming only appears between 2,000 and 3,000 years later in continental Europe and up to 4,000 years later in Northern and Northwestern Europe [31, 32]. How farming economies spread is still a matter of debate, but it seems that expanding farming populations from the Near East introduced their economies over much of Europe [33-35], with the exception of some areas, where it may have been adopted by local hunter-gatherer populations $[31,36]$. This population expansion can be defined by a small population growing in size and by expanding its geographical range [37, 38]. This population expansion, associated with farming,

The Onset of Lactase Persistence in Europe has been suggested from diverse sources of archaeological evidence including an increase in fertility [39] inferred from a higher proportion of young individuals in Neolithic cemeteries and a higher population density inferred from a higher density of radiocarbon dates in Neolithic times in comparison to earlier periods [31,40].

With respect to the onset of dairying, the age and sex distribution of animals (at death) in archaeological skeletal assemblages have suggested that more female animals were kept alive to be milked in Near Eastern archaeozoological sites dated to around 10,500 years BP onwards than in earlier (late Mesolithic) sites [41-44]. Further archaeological evidence for the intensification of dairying comes from the detection of dairy fat residues in potsherds by a combination of individual fatty acid discrimination and measurements of stable isotope ratios. The use of dairy products has by these means been observed (fig. 1) as early as 8,500 years BP [45] in the Northwest of presentday Turkey, around 7,900-7,450 years BP [46] at Neolithic sites in Romania and Hungary and around 6,100 years $\mathrm{BP}$ in Britain [47]. These dates lie near or at the time when farming developed in the respective regions, indicating that dairying was an early feature of the Neolithic lifestyle.

The archaeological record provides additional information on the evolution of LP in Europe with recent developments in ancient DNA technologies (fig. 1). Indeed, the earliest evidence for the presence of $-13910^{*} \mathrm{~T}$ in ancient DNA European samples is in late Scandinavian hunter-gatherers (with a frequency of $5 \%$ ) dated from $5,400-3,400$ years BP [48] and at about the same time (between 5,000 and 4,500 BP, with a frequency of 26 and $11 \%$ ) in early Neolithic farmers from Northwestern Spain [49]. The allele is, however, absent from early Neolithic farmer samples from other regions [50-52]. Less surprisingly, it has been observed in Medieval samples from Northeastern Europe (a single sample dated to 400-600 $\mathrm{AD}$, which was heterozygous [50]) and from CentralEastern Europe (with a frequency of $11 \%$ in samples dated to 1012-1112 AD [53]). Considering both the low frequency/rarity of the $-13910^{*} \mathrm{~T}$ allele in Neolithic samples [50-52] together with the archaeological evidence of dairying [45] suggests that dairying was practiced before LP arose or became common (fig. 1).

\section{Natural Selection and Demography}

Assuming dairying reflects the cultural trait of milk drinking and consequently a potential selection pressure, the selection pressure predates the occurrence of the ad- 
Fig. 1. Ancient DNA evidence of the $-13910^{*} T$ allele and occurrence of dairy fat residues in potsherds from the archaeological record. The chart size reflects the sample size and is color-coded, going from red (for older samples) to cream (for the most recent samples), representing the frequency of the ancestral $-13910^{*} \mathrm{C}$ allele (the frequency of the $-13910^{*} T$ allele, associated with LP in Europe, is given in black). Blue symbols indicate the locations of Neolithic sites from which lipid residue analyses were performed on potsherds (with the detection of dairy residues based on isotopic analyses or molecular criteria for well-preserved residues): circles = milk fats were undetectable; diamonds $=$ the detected proportion of milk fats was $<30 \%$; triangles $=$ the detected proportion of milk fats was $>30 \%$. med. time $=$ The median time of sampling of ancient DNA, given in years BP. The data were taken from: ** Burger et al. [50]; " Lacan et al. [52]; + Plantinga et al. [49]; ' Lacan et al. [51]; * Malmström et al. [48]; $\wedge$ Nagy et al. [101]. The data on lipid residue analyses are from [45-47, 77, 94-98]. The figure is adapted from Gerbault et al. [99].

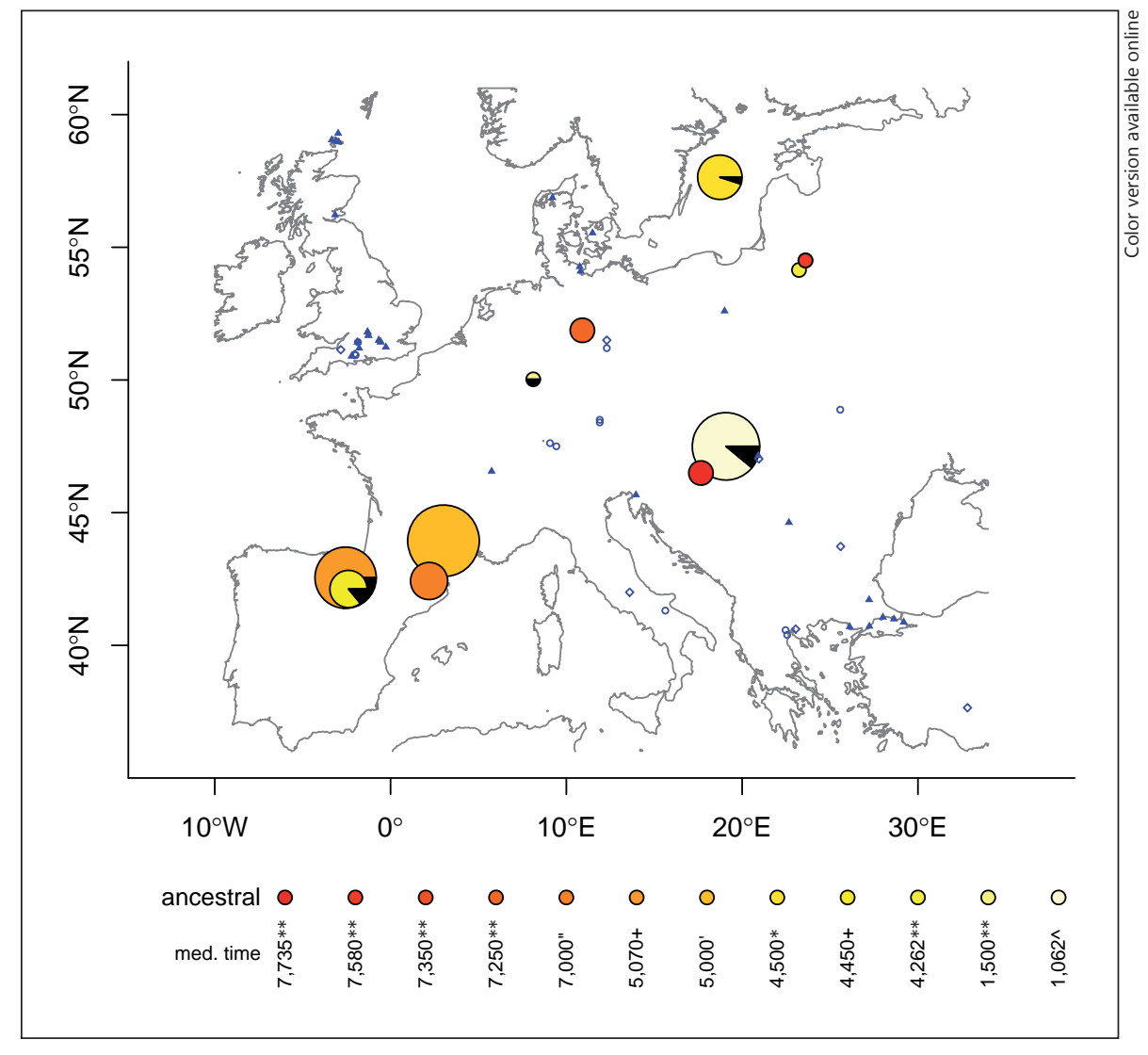

vantageous allele (i.e. $-13910^{*} \mathrm{~T}$ ) in these populations. This model of selection is sometimes referred to as 'selection on a de novo mutation' in opposition to 'selection from standing variation', where alleles are already present at a reasonable frequency when the selective pressure occurs [54]. A recent study using a coalescent approach coupled with an approximate Bayesian framework [15] showed that the selection on LCT in European genomes was more likely to be a case of selection from a de novo mutation than from standing variation. The occurrence of the allele at a low frequency at the time when the selective pressure arose is perhaps the most reasonable scenario.

It is worth mentioning that whether selection from a de novo mutation or from standing variation is more likely may not only depend on the timing of when the mutation arises in relation to when the selective pressure occurs, but it may also depend on the effective size of the population considered. In other words, the larger the population, the larger the number of variants that can remain in that population and the more likely a selection from standing variation. This corroborates what we know about the evolution of LP in Africa and Europe. Indeed, in the former, LP is associated with multiple beneficial alleles - and could be an example of 'soft sweep' - [22, 23, $25,55]$, and the estimated population sizes are generally larger than those estimated for Eurasia [56, 57]. Accordingly, LP in Europeans has so far been associated with a single beneficial allele - and could be a case of "hard sweep' [24, 58].

Furthermore, it is noteworthy that this recent study [15] used the observed allele frequency of the modern Finnish population sample for fitting the modeled $-13910^{*} T$ allele trajectory. Amongst other features required for testing the case of selection from a de novo mutation or standing variation [15], this population sample was chosen because it has a high frequency of the positively selected allele, without it being fixed. Nonetheless, the $-13910^{*} T$ allele frequency varies quite substantially within Europe (fig. 2). For example, while it can reach frequencies as high as $81.5 \%$ in Sweden or $68.8 \%$ in Great Britain [6], it can be as low as $3.1 \%$ in Turkey [18] or $8.5 \%$ in Sicily [59]. While it is often assumed that the location where an allele is most frequent is its location of origin, it 
Fig. 2. The current geographic distribution of the $-13910^{*} T$ allele in European populations. The chart size does not reflect the sample size. The data on the $-13910^{*} \mathrm{~T}$ allele frequencies (portion in black) are from $[6,18,59,100-103]$.

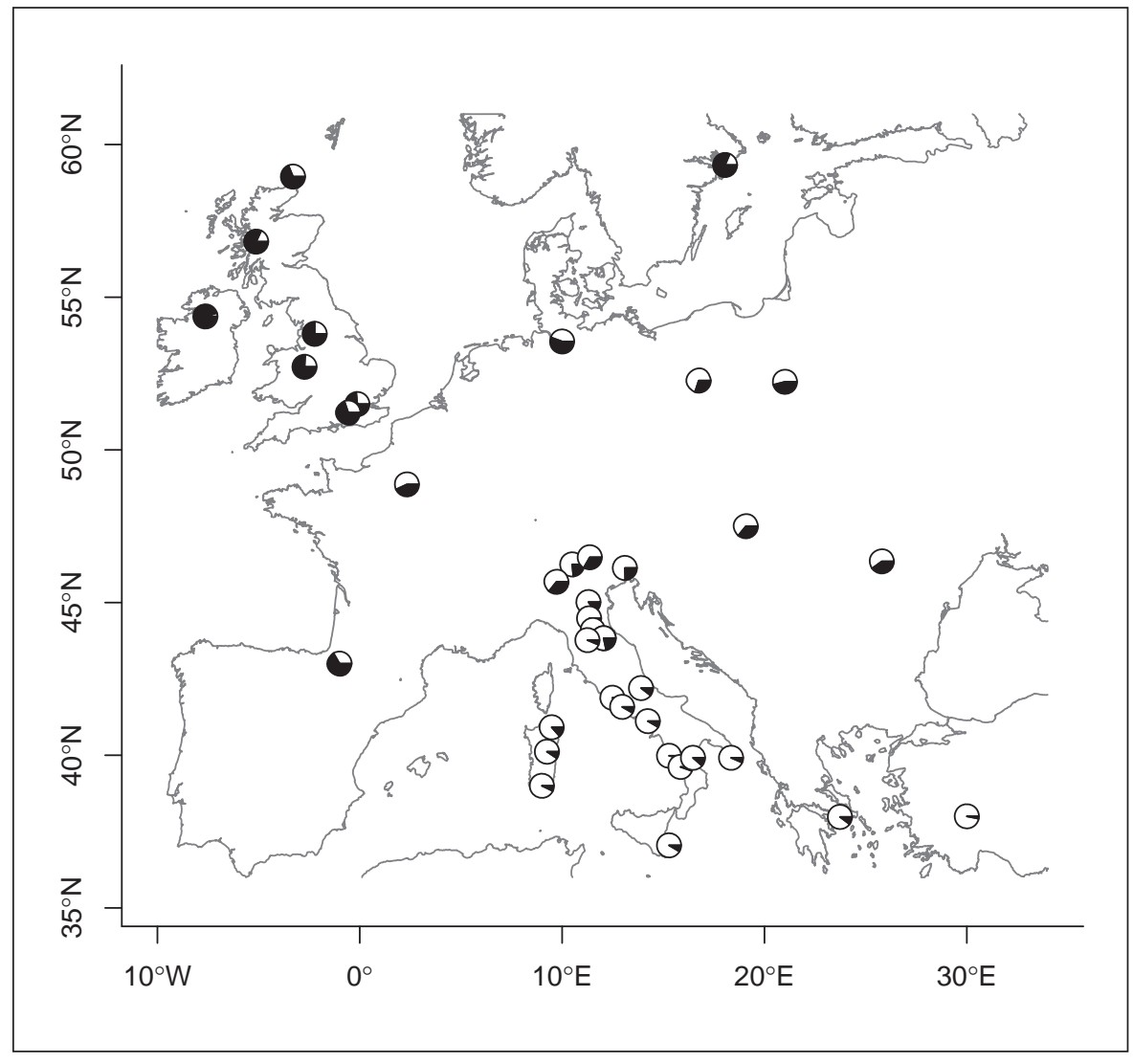

has recently been shown that this is not always the case $[60,61]$. Indeed, similar patterns can be produced by a phenomenon called 'allele surfing' occurring during a spatial population expansion [60-65], as may have been the case in the context of the Neolithic expansion.

Allele surfing can happen in any allele, derived or ancestral, neutral, advantageous or deleterious, but the spatial distribution of allele frequencies may be different depending on its selection status - neutral, advantageous or deleterious [62]. This phenomenon is nonetheless more likely to be identified when a rare allele has surfed successfully, generating a gradient of allele frequency between its location of origin and the wave front of advance. Allele surfing is more frequent when the population size and the migration rate are small, because then the founder effect in newly colonized habitat strengthens the effect of genetic drift and leaves more opportunities for an allele that has been rare to reach higher frequencies [61].

In the case of LP and the $-13910^{*} T$ allele, Itan et al. [17] used a spatially explicit model, simulating the range expansion of farmers from the Near East into Europe, to infer the location where selection on this European allele

The Onset of Lactase Persistence in Europe may have started: in Central Europe, at a place where (and a time when) an archaeological culture called the 'Linearbandkeramik' (LBK) based on cattle economy was spreading Northwest. In this model, the allele remained at low frequencies where it first appeared and was selected and rose in frequency as farming populations expanded Northwest. During such a range expansion, allele surfing can also produce similar patterns for neutral alleles, and the extent to which the $-13910^{*} T$ frequency trajectory can be obtained without selection during a spatial expansion remains to be formally assessed. Along these lines, a demic simulation study [16] suggested that selection of the $-13910^{*} T$ allele may not have been as high in Southern Europe as it may have been in Northern Europe.

Interestingly, Bersaglieri et al. [6] inferred that for a Scandinavian population sample of parent-offspring trios the selection pressure was stronger and the allele more recent than if other European-derived US pedigree samples were considered (i.e. a selection of $9-19$ vs. $1.4-15 \%$ and a time range of between 1,625 and 3,188 vs. 2,188 and 20,650 years ago in Scandinavian vs. other European samples, respectively). However, the significance of these differences 
on the continental scale may reflect other demographic or ancestry effects $[33,34,66]$. Furthermore, disentangling the effect of natural selection over that of demographic range expansion is made difficult because range expansions and allele surfing can substantially affect the genetic diversity of an expanding population $[63,65,67,68]$.

\section{Why Would LP Have Been Advantageous in Europe?}

Additional environmental features at the onset of the Neolithic need to be considered to have an appreciation of the context in which LP may have evolved. On the one hand, the development of farming and agriculture occurred during the Holocene, a period when the climate was becoming warmer and may have promoted human migrations in the Near East and in Europe [40, 69-71]. Climate may thus have affected the $-13910^{*} T$ allele distribution to the extent that it affected human migrations. On another hand, with the intensification of agriculture and domestication, the food range of agricultural and farming populations is known to have become narrower in comparison to that of hunter-gatherers [72-75]. Even though the consumption of milk and dairy products may thus have provided a good nutritional component to the diet of farmers [76], the identification of cheese-strainers from 7,150 to 6,750 years BP [77] suggests that lactase-nonpersistent adults may have consumed dairy products without experiencing symptoms of lactose intolerance early in the Neolithic. However, boom-and-bust patterns of farming populations due to early farming practices [32] or the not yet locally adapted domesticated species [78-81] may have provided a temporally and spatially limited selective pressure sufficient to drive the $-13910^{*} T$ allele to high frequencies in modern-day European populations. This, however, remains very speculative.

The hypothesis of an environmental variable shaping the co-evolutionary process between dairying and LP in Europe has been suggested previously in terms of the calcium assimilation hypothesis [82]. In this hypothesis, the positive correlation between LP frequency and latitude led Flatz and Rotthauwe [82] to suggest that because of the calcium content and small amount of vitamin D in milk, LP may have provided a good supplement of both against the lack of UVB sunlight at higher latitude. Latitude - or more specifically the lack of sunlight - would be the selective pressure advantaging LP in adults. Before Northern Europeans started to rely on farming, a lack of sunlight (at high latitudes) may not have been an issue, since the diet of European pre-Neolithic hunter-gatherers would have been rich in marine sources [83]. However, while the archaeological record provides evidence for less healthy Neolithic populations in comparison to Upper Paleolithic and Mesolithic ones [74, 84-86], there is no evidence for a higher incidence of rickets (i.e. severe vitamin $\mathrm{D}$ deficiency) in Neolithic archaeological assemblages [86]. It is possible, however, that mild vitamin $\mathrm{D}$ deficiency, which may be more complex to assess from archaeological remains, would be selectively disadvantageous $[87,88]$.

\section{Conclusion}

There are molecular signals of strong directional selection in the genomic region surrounding a single nucleotide variant, present in Europeans, that has been shown to affect the expression of the $L C T$ gene both in vitro and in vivo. The existence of other alleles in this sequence region, in adults from different populations, is evidence of parallel or convergent evolution. These alleles also affect the persistence of lactase activity and may show a different signature of selection. The correlation between LP - and LP-associated mutations identified so far - and pastoralist/milk drinking populations $[5,29,30]$ provides strong support for a co-evolutionary process between a cultural (dairying) and a genetic trait. This underlines the evolution of LP as a good example of gene-culture co-evolution $[26,89-92]$. This correlation between the cultural skill of dairying and the occurrence of LP in human populations also provides a good example of the type of dietary adaptation the Neolithic period entailed [73, 93]. The reasons why LP may have been advantageous remain to be clarified and the respective contribution of natural selection and spatial range expansion in shaping the $-13910^{*} \mathrm{~T}$ allele trajectory to be disentangled. This research has nonetheless benefitted from diverse sources, including ancient and modern DNA data, lipid residue and achaeozoological analyses, ancient population demographic studies and population genetics. The integration of such a diverse source of information has shed a better understanding of the processes underlying the evolution of LP.

\section{Acknowledgements}

I thank the organizers of the conference 'Genetic Diversity and Origins of Europeans', especially Alicia Sanchez-Mazas. I also thank Robin Allaby, Melanie Roffet-Salque and Richard Evershed for their insights, and especially Dallas Swallow and two anonymous reviewers for commenting on a former version of this paper. I also thank the EU FP7 ITN (LeCHE grant) for funding this research. 


\section{References}

1 Arribas JC, Herrero AG, Martín-Lomas M, 16 Gerbault P, Moret C, Currat M, Sanchez-MaCañada FJ, He S, Withers SG: Differential mechanism-based labeling and unequivocal activity assignment of the two active sites of intestinal lactase/phlorizin hydrolase. Eur J Biochem 2000;267:6996-7005.

-2 Swallow DM: Genetic influences on carbohydrate digestion. Nutr Res Rev 2003;16:37-43.

-3 Ingram CJ, Swallow DM: Lactose malabsorption, in McSweeney PLH, Fox PF (eds): Advanced Dairy Chemistry - Volume 3: Lactose, Water, Salts and Minor Constituents, New York, Springer, 2009, pp 203-229.

-4 Troelsen JT: Adult-type hypolactasia and regulation of lactase expression. Biochim Biophys Acta 2005;1723:19-32.

5 Itan Y, Jones BL, Ingram CJ, Swallow DM, Thomas MG: A worldwide correlation of lactase persistence phenotype and genotypes. BMC Evol Biol 2010;10:36.

6 Bersaglieri T, Sabeti PC, Patterson N, Vanderploeg T, Schaffner SF, Drake JA, Rhodes M, Reich DE, Hirschhorn JN: Genetic signatures of strong recent positive selection at the lactase gene. Am J Hum Genet 2004;74:11111120.

$>7$ Voight BF, Kudaravalli S, Wen X, Pritchard JK: A map of recent positive selection in the human genome. PLoS Biol 2006;4:e72.

$>8$ Sabeti PC, Schaffner SF, Fry B, Lohmueller J, Varilly P, Shamovsky O, Palma A, Mikkelsen TS, Altshuler D, Lander ES: Positive natural selection in the human lineage. Science 2006; 312:1614-1620.

$>9$ Coelho M, Luiselli D, Bertorelle G, Lopes AI, Seixas S, Destro-Bisol G, Rocha J: Microsatellite variation and evolution of human lactase persistence. Hum Genet 2005;117:329-339.

$>10$ Hofer T, Foll M, Excoffier L: Evolutionary forces shaping genomic islands of population differentiation in humans. BMC Genomics 2012;13:107.

$>11$ Akey JM, Zhang G, Zhang K, Jin L, Shriver $\mathrm{MD}$ : Interrogating a high-density SNP map for signatures of natural selection. Genome Res 2002;12:1805-1814.

$>12$ Fang L, Ahn JK, Wodziak D, Sibley E: The human lactase persistence-associated SNP $-13910 * \mathrm{~T}$ enables in vivo functional persistence of lactase promoter-reporter transgene expression. Hum Genet 2012;131:1153-1159.

$>13$ Olds LC, Sibley E: Lactase persistence DNA variant enhances lactase promoter activity in vitro: functional role as a cis regulatory element. Hum Mol Genet 2003;12:2333-2340.

-14 Troelsen JT, Olsen J, Møller J, Sjöström H: An upstream polymorphism associated with lactase persistence has increased enhancer activity. Gastroenterology 2003;125:1686-1694.

15 Peter BM, Huerta-Sanchez E, Nielsen R: Distinguishing between selective sweeps from standing variation and from a de novo mutation. PLoS Genet 2012;8:e1003011. zas A: Impact of selection and demography on the diffusion of lactase persistence. PLoS One 2009; 4:e6369.

17 Itan Y, Powell A, Beaumont MA, Burger J, Thomas MG: The origins of lactase persistence in Europe. PLoS Comput Biol 2009; 5:e1000491.

18 Mulcare CA: The Evolution of the Lactase Persistence Phenotype; thesis, University of London, London, 2006. Al-Kahtani K, Kagevi I, Rashed MS, Meyer BF, Järvelä I: The T/G 13915 variant upstream of the lactase gene (LCT) is the founder allele of lactase persistence in an urban Saudi population. J Med Genet 2007;44:e89.

20 Ingram CJ, Elamin MF, Mulcare CA, Weale ME, Tarekegn A, Raga TO, Bekele E, Elamin FM, Thomas MG, Bradman N, Swallow DM: A novel polymorphism associated with lactose tolerance in Africa: multiple causes for lactase persistence? Hum Genet 2007;120: 779-788.

21 Ingram CJ, Raga TO, Tarekegn A, Browning SL, Elamin MF, Bekele E, Thomas MG, Weale ME, Bradman N, Swallow DM: Multiple rare variants as a cause of a common phenotype: several different lactase persistence associated alleles in a single ethnic group. J Mol Evol

22 Jones BL, Raga TO, Liebert A, Zmarz P, Bekele E, Danielsen ET, Olsen AK, Bradman N, Troelsen JT, Swallow DM: Diversity of lactase persistence alleles in Ethiopia: signature of a soft selective sweep. Am J Hum Genet 2013;93:538-544.

23 Tishkoff SA, Reed FA, Ranciaro A, Voight BF, Babbitt CC, Silverman JS, Powell K, Mortensen HM, Hirbo JB, Osman M, Ibrahim M, Omar SA, Lema G, Nyambo TB, Ghori J, Bumpstead S, Pritchard JK, Wray GA, Deloukas P: Convergent adaptation of human lactase persistence in Africa and Europe. Nat Genet 2007;39:31-40.

24 Enattah NS, Sahi T, Savilahti E, Terwilliger JD, Peltonen L, Järvelä I: Identification of a variant associated with adult-type hypolactasia. Nat Genet 2002;30:233-237.

25 Enattah NS, Trudeau A, Pimenoff V, Maiuri L, Auricchio S, Greco L, Rossi M, Lentze M, Seo JK, Rahgozar S, Khalil I, Alifrangis M, Natah S, Groop L, Shaat N, Kozlov A, Verschubskaya G, Comas D, Bulayeva K, Mehdi SQ, Terwilliger JD, Sahi T, Savilahti E, Perola M, Sajantila A, Järvelä I, Peltonen L: Evidence of still-ongoing convergence evolution of the lactase persistence T-13910 alleles in humans. Am J Hum Genet 2007;81:615-625.

26 Gerbault P, Liebert A, Itan Y, Powell A, Currat M, Burger J, Swallow DM, Thomas MG: Evolution of lactase persistence: an example of human niche construction. Philos Trans R Soc Lond B Biol Sci 2011;366:863-877.
19 Imtiaz F, Savilahti E, Sarnesto A, Trabzuni D 2009;69:579-588
27 Leonardi M, Gerbault P, Thomas GM, Burger $\mathrm{J}$ : The evolution of lactase persistence in Europe. A synthesis of archaeological and genetic evidence. Int Dairy J 2012;22:88-97.

28 Ingram CJ, Mulcare CA, Itan Y, Thomas MG, Swallow DM: Lactose digestion and the evolutionary genetics of lactase persistence. Hum Genet 2009;124:579-591.

29 Holden C, Mace R: Phylogenetic analysis of the evolution of lactose digestion in adults. Hum Biol 1997;69:605-628.

30 Simoons FJ: Primary adult lactose intolerance and the milking habit: a problem in biologic and cultural interrelations. II. A culture historical hypothesis. Am J Dig Dis 1970;15:695710 .

31 Shennan S: Evolutionary demography and the population history of the European early Neolithic. Hum Biol 2009;81:339-355.

-32 Shennan S, Downey SS, Timpson A, Edinborough K, Colledge S, Kerig T, Manning K, Thomas MG: Regional population collapse followed initial agriculture booms in midHolocene Europe. Nat Commun 2013;4:2486.

33 Bramanti B, Thomas MG, Haak W, Unterlaender M, Jores P, Tambets K, AntanaitisJacobs I, Haidle MN, Jankauskas R, Kind CJ, Lueth F, Terberger T, Hiller J, Matsumura S, Forster P, Burger J: Genetic discontinuity between local hunter-gatherers and central Europe's first farmers. Science 2009;326:137140.

34 Malmstrom H, Gilbert MT, Thomas MG, Brandström M, Storå J, Molnar P, Andersen PK, Bendixen C, Holmlund G, Götherström A, Willerslev E: Ancient DNA reveals lack of continuity between neolithic hunter-gatherers and contemporary Scandinavians. Curr Biol 2009;19:1758-1762.

35 Skoglund P, Malmström H, Raghavan M, Storå J, Hall P, Willerslev E, Gilbert MT, Götherström A, Jakobsson M: Origins and genetic legacy of Neolithic farmers and huntergatherers in Europe. Science 2012;336:466469 .

36 Zvelebil M: The social context of the agricultural transition in Europe; in Renfrew C, Boyle K (eds): Archaeogenetics: DNA and the Population Prehistory of Europe. Cambridge, McDonald Institute for Archaeological Research, 2000, pp 57-79.

37 Currat M: Consequences of population expansions on European genetic diversity; in Kaiser E, Burger J, Schier W (eds): Population Dynamics in Prehistory and Early History: New Approaches Using Stable Isotopes and Genetics. Berlin, De Gruyter, 2012, vol 5, pp 3-15.

38 Ammerman AJ, Cavalli-Sforza LL: The Neolithic Transition and the Genetics of Populations in Europe. Princeton, Princeton University Press, 1984.
The Onset of Lactase Persistence in Europe
Hum Hered 2013;76:154-161 DOI: $10.1159 / 000360136$ 
-39 Bocquet-Appel JP, Naji S: Testing the hypothesis of a worldwide Neolithic demographic transition. Corroboration from American cemeteries (with comments). Curr Anthropol 2006; $47: 341-365$.

40 Shennan S, Edinborough K: Prehistoric population history: from the Late Glacial to the Late Neolithic in Central and Northern Europe. J Archaeol Sci 2007;34:1339-1345.

41 Vigne JD: Zooarchaeological aspects of the Neolithic diet transition in the Near East and Europe, and their putative relationships with the Neolithic demographic transition; in Bocquet-Appel JP, Bar-Yosef O (eds): The Neolithic Demographic Transition and Its Consequences. Houten, Springer, 2008, pp 179-205.

42 Vigne JD, Carrere I, Guilaine J: Unstable status or early domestic ungulates in the Near East: the example of Shillourokambos (Cyprus, IX-VIIIth millenia cal. BC); in Guilaine J, Le Brun A (eds): Actes du colloque international organisé par le Département des Antiquités de Chypre et l'École française d'Athènes. Nicosia, École française d'Athènes, 2001.

43 Balasse M, Tresset A: Early weaning of Neolithic domestic cattle (Bercy, France) revealed by intra-tooth variation in nitrogen isotope ratios. J Archaeol Sci 2002;29:853-859.

44 Helmer D, Gourichon LL, Vila E: The development of the exploitation of products from Capra and Ovis (meat, milk and fleece) from the PPNB to the Early Bronze in the northern Near East (8700 to $2000 \mathrm{BC}$ cal.). Anthropozoologica 2007;42:41-69.

-45 Evershed RP, Payne S, Sherratt AG, Copley MS, Coolidge J, Urem-Kotsu D, Kotsakis K, Ozdoğan M, Ozdoğan AE, Nieuwenhuyse $\mathrm{O}$, Akkermans PM, Bailey D, Andeescu RR, Campbell S, Farid S, Hodder I, Yalman N, Ozbaşaran M, Biçakci E, Garfinkel Y, Levy T, Burton MM: Earliest date for milk use in the Near East and southeastern Europe linked to cattle herding. Nature 2008;455:528-531.

46 Craig OE, Chapman J, Heron C, Willis LH, Bartosiewicz L, Taylor G, Whittle A, Collins M: Did the first farmers of central and eastern Europe produce dairy foods? Antiquity 2005; 79:882-894.

47 Copley MS, Berstan R, Mukherjee AJ, Dudd SN, Straker V, Payne S, Evershed PR: Dairying in antiquity. III. Evidence from absorbed lipid residues dating to the British Neolithic. J Archaeol Sci 2005;32:523-546.

-48 Malmström H, Linderholm A, Lidén K, Storå J, Molnar P, Holmlund G, Jakobsson M, Götherström A: High frequency of lactose intolerance in a prehistoric hunter-gatherer population in northern Europe. BMC Evol Biol 2010;10:89.

49 Plantinga TS, Alonso S, Izagirre N, Hervella M, Fregel R, van der Meer JW, Netea MG, de la Rúa C: Low prevalence of lactase persistence in Neolithic South-West Europe. Eur J Hum Genet 2012;20:778-782.
50 Burger J, Kirchner M, Bramanti B, Haak W, Thomas MG: Absence of the lactase-persistence-associated allele in early Neolithic Europeans. Proc Natl Acad Sci USA 2007;104: 3736-3741.

51 Lacan M, Keyser C, Ricaut FX, Brucato N, Duranthon F, Guilaine J, Crubézy E, Ludes B: Ancient DNA reveals male diffusion through the Neolithic Mediterranean route. Proc Natl Acad Sci USA 2011;108:9788-9791.

52 Lacan M, Keyser C, Ricaut FX, Brucato N, Tarrús J, Bosch A, Guilaine J, Crubézy E, Ludes B: Ancient DNA suggests the leading role played by men in the Neolithic dissemination. Proc Natl Acad Sci USA 2011;108: 18255-18259.

53 Nagy D, Bogácsi-Szabó E, Várkonyi A, Csányi B, Czibula A, Bede O, Tari B, Raskó I: Prevalence of adult-type hypolactasia as diagnosed with genetic and lactose hydrogen breath tests in Hungarians. Eur J Clin Nutr 2009;63:909912.

54 Hermisson J, Pennings PS: Soft sweeps: molecular population genetics of adaptation from standing genetic variation. Genetics 2005; 169:2335-2352.

55 Enattah NS, Jensen TG, Nielsen M, Lewinski R, Kuokkanen M, Rasinpera H, El-Shanti H, Seo JK, Alifrangis M, Khalil IF, Natah A, Ali A, Natah S, Comas D, Mehdi SQ, Groop L, Vestergaard EM, Imtiaz F, Rashed MS, Meyer B, Troelsen J, Peltonen L: Independent introduction of two lactase-persistence alleles into human populations reflects different history of adaptation to milk culture. Am J Hum Genet $2008 ; 82: 57-72$.

56 Garrigan D, Kingan SB, Pilkington MM, Wilder JA, Cox MP, Soodyall H, Strassmann B, Destro-Bisol G, de Knijff P, Novelletto A, Friedlaender J, Hammer MF: Inferring human population sizes, divergence times and rates of gene flow from mitochondrial, $\mathrm{X}$ and $\mathrm{Y}$ chromosome resequencing data. Genetics 2007;177:2195-2207.

57 Li H, Durbin R: Inference of human population history from individual whole-genome sequences. Nature 2011;475:493-496.

58 Poulter M, Hollox E, Harvey CB, Mulcare C, Peuhkuri K, Kajander K, Sarner M, Korpela $\mathrm{R}$, Swallow DM: The causal element for the lactase persistence/non-persistence polymorphism is located in a $1 \mathrm{Mb}$ region of linkage disequilibrium in Europeans. Ann Hum Genet 2003;67(Pt 4):298-311.

59 Anagnostou P, Battaggia C, Coia V, Capelli C, Fabbri C, Pettener D, Destro-Bisol G, Luiselli $\mathrm{D}$ : Tracing the distribution and evolution of lactase persistence in Southern Europe through the study of the $\mathrm{T}(-13910)$ variant. Am J Hum Biol 2009;21:217-219.

60 Edmonds CA, Lillie AS, Cavalli-Sforza LL: Mutations arising in the wave front of an expanding population. Proc Natl Acad Sci USA 2004;101:975-979.

61 Klopfstein S, Currat M, Excoffier L: The fate of mutations surfing on the wave of a range expansion. Mol Biol Evol 2006;23:482-490.
62 Excoffier L, Foll M, Petit RJ: Genetic consequences of range expansions. Ann Rev Ecol Evol Syst 2009;40:481-501.

63 Excoffier L, Ray N: Surfing during population expansions promotes genetic revolutions and structuration. Trends Ecol Evol 2008;23:347351.

64 François O, Currat M, Ray N, Han E, Excoffier L, Novembre J: Principal component analysis under population genetic models of range expansion and admixture. Mol Biol Evol 2010;27:1257-1268

65 Hallatschek O, Nelson DR: Life at the front of an expanding population. Evolution 2009;64: 193-206.

66 von Cramon-Taubadel N, Pinhasi R: Craniometric data support a mosaic model of demic and cultural Neolithic diffusion to outlying regions of Europe. Proc Biol Sci 2011;278: 2874-2880.

67 Currat M, Excoffier L: Modern humans did not admix with Neanderthals during their range expansion into Europe. PLoS Biol 2004; 2:e421.

68 Currat M, Ruedi M, Petit RJ, Excoffier L: The hidden side of invasions: massive introgression by local genes. Evolution 2008;62:19081920.

69 Gonzalez-Samperiz P, Utrilla P, Mazo C, Valero-Garcés B, Sopena MC, Morellón M, Sebastián M, Moreno A, Martínez-Bea M: Patterns of human occupation during the early Holocene in the Central Ebro Basin (NE Spain) in response to the $8.2 \mathrm{ka}$ climatic event. Quat Res (Orlando) 2009;71:121-132.

-70 Turney C, Brown H: Catastrophic early Holocene sea level rise, human migration and the Neolithic transition in Europe. Quat Sci Rev 2007;26:2036-2041.

71 Weninger B, Alram-Stern E, Bauer E, Clare L, Danzeglocke U, Jöris O, Kubatzki C, Rollefson $\mathrm{G}$, Todorova $\mathrm{H}$, van Andel T: Climate forcing due to the $8200 \mathrm{cal} \mathrm{yr} \mathrm{BP}$ event observed at Early Neolithic sites in the eastern Mediterranean. Quat Res 2006;66:401-420.

72 Cordain L, Miller JB, Eaton SB, Mann N, Holt SH, Speth JD: Plant-animal subsistence ratios and macronutrient energy estimations in worldwide hunter-gatherer diets. Am J Clin Nutr 2000;71:682-692.

73 Luca F, Perry GH, Di Rienzo A: Evolutionary adaptations to dietary changes. Annu Rev Nutr 2010;30:291-314

74 Richards MP: A brief review of the archaeological evidence for Palaeolithic and Neolithic subsistence. Eur J Clin Nutr 2002;56:16 p following 1262

75 Lösch S, Grupe G, Peters J: Stable isotopes and dietary adaptations in humans and animals at pre-pottery Neolithic Nevali Cori, southeast Anatolia. Am J Phys Anthropol 2006;131: 181-193.

76 Bogucki PI: Ceramic sieves of the linear pottery culture and their economic implications. Oxf J Archaeol 1984;3:15-30. 
77 Salque M, Bogucki PI, Pyzel J, SobkowiakTabaka I, Grygiel R, Szmyt M, Evershed RP: Earliest evidence for cheese making in the sixth millennium BC in northern Europe. Nature 2013;493:522-525.

$>78$ Cockram J, Jones H, Leigh FJ, O’Sullivan D, Powell W, Laurie DA, Greenland AJ: Control of flowering time in temperate cereals: genes, domestication, and sustainable productivity. J Exp Bot 2007;58:1231-1244.

79 Fu D, Szücs P, Yan L, Helguera M, Skinner JS, von Zitzewitz J, Hayes PM, Dubcovsky J: Large deletions within the first intron in VRN-1 are associated with spring growth habit in barley and wheat. Mol Genet Genomics 2005;273:54-65.

80 Stevens CJ, Fuller DQ: Did Neolithic farming fail? The case for a Bronze Age agricultural revolution in the British Isles. Antiquity 2012 86:707-722

-81 Wu W, Zheng XM, Lu G, Zhong Z, Gao H, Chen L, Wu C, Wang HJ, Wang Q, Zhou K, Wang JL, Wu F, Zhang X, Guo X, Cheng Z, Lei C, Lin Q, Jiang L, Wang H, Ge S, Wan J: Association of functional nucleotide polymorphisms at DTH2 with the northward expansion of rice cultivation in Asia. Proc Natl Acad Sci USA 2013;110:2775-2780.

$>82$ Flatz G, Rotthauwe HW: Lactose nutrition and natural selection. Lancet 1973;2:76-77.

-83 Richards MP, Schulting RJ, Hedges RE: Archaeology: sharp shift in diet at onset of Neolithic. Nature 2003;425:366.

-84 Eshed V, Gopher A, Pinhasi R, Hershkovitz I: Paleopathology and the origin of agriculture in the Levant. Am J Phys Anthropol 2010;143. 121-133.

85 Holt BM, Formicola V: Hunters of the Ice Age: the biology of Upper Paleolithic people. Am J Phys Anthropol 2008;(suppl 47):70-99.

86 Larsen CS: Biological changes in human populations associated with agriculture. Annu Rev Anthropol 1995;24:185-213.
87 Basit S: Vitamin D in health and disease: a literature review. Br J Biomed Sci 2013;70:161172.

88 Bouillon R, Bischoff-Ferrari H, Willett W: Vitamin D and health: perspectives from mice and man. J Bone Miner Res 2008;23:974-979.

89 Durham WH: The relationship of genes and culture; in Durham WH (ed): Coevolution: Genes, Culture and Human Diversity. Stanford, Stanford University Press, 1991, pp 154225.

90 Durham WH: Cultural mediation: the evolution of adult lactose absorption, in Durham WH (ed): Coevolution: Genes, Culture and Human Diversity. Stanford, Stanford University Press, 1991, pp 226-285.

91 Laland KN: Exploring gene-culture interactions: insights from handedness, sexual selection and niche-construction case studies. Philos Trans R Soc Lond B Biol Sci 2008;363: 3577-3589.

92 Laland KN, Odling-Smee J, Myles S: How culture shaped the human genome: bringing genetics and the human sciences together. Nat Rev Genet 2010;11:137-148.

93 Hancock AM, Witonsky DB, Ehler E, Alkorta-Aranburu G, Beall C, Gebremedhin A, Sukernik R, Utermann G, Pritchard J, Coop G, Di Rienzo A: Colloquium paper: human adaptations to diet, subsistence, and ecoregion are due to subtle shifts in allele frequency. Proc Natl Acad Sci USA 2010;107(suppl 2):8924-8930.

94 Berstan R, Stott AW, Minnitt S, Bronk Ramsey C, Hedges REM, Evershed RP: Direct dating of pottery from its organic residues: new precision using compound-specific carbon isotopes. Antiquity 2008;82:702-713.

95 Copley MS, Berstan R, Dudd SN, Aillaud S, Mukherjee AJ, Straker V, Payne S, Evershed RP: Processing of milk products in pottery vessels through British prehistory. Antiquity 2005;79:895-908.
96 Gregg MW, Banning EB, Gibbs K, Slater GF: Subsistence practices and pottery use in Neolithic Jordan: molecular and isotopic evidence. J Archaeol Sci 2009;36:937-946.

$\checkmark 97$ Mirabaud S, Rolando C, Regert M: Molecular criteria for discriminating adipose fat and milk from different species by nanoESI MS and MS/MS of their triacylglycerols: application to archaeological remains. Anal Chem 2007;79:6182-6192.

98 Salque M, et al: Erratum to: New insights into the Early Neolithic economy and management of animals in Southern and Central Europe revealed using lipid residue analyses of pottery vessels. Anthropozoologica 2012; 47:45-62.

99 Gerbault P, Roffet-Salque M, Evershed RP, Thomas MG: How long have adult humans been consuming milk? IUBMB Life 2013;65: 983-990.

100 Mądry E, Lisowska A, Kwiecień J, Marciniak R, Korzon-Burakowska A, Drzymała-Czyż S, Mojs E, Walkowiak J: Adult-type hypolactasia and lactose malabsorption in Poland. Acta Biochim Pol 2010;57:585-588.

101 Nagy D, Tömöry G, Csányi B, Bogácsi-Szabó E, Czibula Á, Priskin K, Bede O, Bartosiewicz L, Downes CS, Raskó I: Comparison of lactase persistence polymorphism in ancient and present-day Hungarian populations. Am J Phys Anthropol 2011;145:262-269.

102 Ptoszaj T, Jedrychowska-Danska K, Witas HW: Frequency of lactase persistence genotype in a healthy Polish population. Cent Eur J Biol 2011;6:176-179.

103 Smith GD, Lawlor DA, Timpson NJ, Baban J, Kiessling M, Day IN, Ebrahim S: Lactase persistence-related genetic variant: population substructure and health outcomes. Eur J Hum Genet 2009;17:357-367.
The Onset of Lactase Persistence in Europe
Hum Hered 2013;76:154-161 